\title{
Effects of predator richness and habitat heterogeneity on prey suppression in an estuarine food chain
}

Leonardo K. Miyashita

Virginia Institute of Marine Science

J. Paul Richardson

Virginia Institute of Marine Science

J. Emmett Duffy

Virginia Institute of Marine Science

Follow this and additional works at: https://scholarworks.wm.edu/vimsarticles

Part of the Marine Biology Commons

\section{Recommended Citation}

Miyashita, Leonardo K.; Richardson, J. Paul; and Duffy, J. Emmett, Effects of predator richness and habitat heterogeneity on prey suppression in an estuarine food chain (2016). Marine Ecology Progress Series, $559,13-20$.

doi: $10.3354 /$ meps 11893

This Article is brought to you for free and open access by the Virginia Institute of Marine Science at W\&M ScholarWorks. It has been accepted for inclusion in VIMS Articles by an authorized administrator of W\&M ScholarWorks. For more information, please contact scholarworks@wm.edu. 


\title{
Effects of predator richness and habitat heterogeneity on prey suppression in an estuarine food chain
}

\author{
Leonardo K. Miyashita ${ }^{1,2, *}$, J. Paul Richardson ${ }^{1}$, J. Emmett Duffy ${ }^{1,3}$ \\ ${ }^{1}$ Department of Biological Sciences, Virginia Institute of Marine Science, The College of William \& Mary, Gloucester Point, \\ VA 23062-1346, USA \\ ${ }^{2}$ Department of Biological Oceanography, Oceanographic Institute, University of São Paulo, São Paulo, SP 05508-120, Brazil \\ ${ }^{3}$ Present address: Tennenbaum Marine Observatories Network, Smithsonian Institution, Washington, DC 20013-7012, USA
}

\begin{abstract}
Predator influence on the structure of prey communities can be mediated by habitat heterogeneity, the effects of which may cascade to the base of the food webs, altering producer biomass and species composition. We carried out a mesocosm experiment manipulating the identity and richness of predators and habitat heterogeneity to test their influence on resource use effectiveness, competition among predators, and trophic cascades in a model estuarine system with 3 trophic levels (microalgae, mysids, and the predators blue crab Callinectes sapidus, sand shrimp Crangon septemspinosa, and grass shrimp Palaemonetes pugio). We hypothesized that increasing predator species richness would increase mysid suppression because of complementarity among predators, that complementarity would be better expressed in more heterogeneous habitats, and that higher mysid suppression would increase algae biomass through cascading effects. Assemblages with multiple predators were more effective at suppressing prey than the average single predator, but not in comparison to the most effective predator (i.e. no transgressive overyielding). Predator diversity effects increased with habitat heterogeneity, possibly because it allowed interspecific complementarity among predators to be expressed. Moreover, habitat heterogeneity dampened intraspecific predation and/or negative behavioral interactions between predators. A trophic cascade was not observed because of the low mysid grazing impact on microalgae, probably related to the omnivorous feeding of mysids. Our findings indicate that the loss of both biodiversity and habitat heterogeneity should alter the energy flux in marine food webs; therefore, both must be considered for the proper management of natural ecosystems.
\end{abstract}

KEY WORDS: Biodiversity - Ecosystem functioning - Habitat structure - Predator richness · Trophic cascade $\cdot$ Food webs $\cdot$ Complementarity $\cdot$ Omnivory

\section{INTRODUCTION}

The loss of biodiversity, i.e. variety of species, genes, or functional traits, has negative consequences for several ecosystem functions, e.g. the capacity of communities to use resources, produce biomass, decompose, and recycle nutrients (Stachowicz et al. 2007, Gamfeldt et al. 2015). Consequently, declines in biodiversity can also impair ecosystem services, such as the production of renewable resources and resistance to climate events (Cardinale et al. 2012, Isbell et al. 2015, Duffy et al. 2016). Most studies concerning biodiversity effects on ecosystem functioning have focused on terrestrial producers (Cardinale et al. 2006, 2011), because they constitute the base of the food webs and are easier to manipulate than consumers in higher trophic levels. Predators, in contrast, usually have complex behaviors and present complex 
trophic interactions, such as intraguild predation (Polis \& Holt 1992, Finke \& Denno 2004). Nevertheless, there is recent evidence that the relationship between species richness effects and consumption is stronger for predators than for producers and detritivores (Griffin et al. 2013, Gamfeldt et al. 2015). Thus, an alteration in predator species identity and diversity may alter top-down controls and cascade through consumers to the base of the food webs (Duffy et al. 2005, 2007, Bruno \& Cardinale 2008).

Experimental evidence shows that ecosystem effects of changing diversity are generally consistent across taxa and ecosystems (Cardinale et al. 2006, Stachowicz et al. 2007); however, the responses may vary considerably according to habitat heterogeneity (Griffin et al. 2009, Godbold et al. 2011). An increase of habitat heterogeneity often strengthens diversity effects, apparently because it allows resource partitioning to be better expressed, i.e. complementarity effects among species to be manifested (Duffy 2009, Griffin et al. 2009). Habitat heterogeneity may be promoted by foundation species, such as oysters, corals, and kelps, which create complex habitats for other species, and are thus often essential for the structure, resilience, and functioning of ecosystems (Gutiérrez et al. 2003, Altieri \& van de Koppel 2014). The biogenic structure of foundation species provides refuge, which attenuates physical and biological stresses (e.g. wave action and predation pressure, respectively), often enabling the coexistence of abundant and diverse communities (Stachowicz 2001). Habitat heterogeneity can also mediate trophic interactions by influencing competition among predators (Grabowski \& Powers 2004, Hughes \& Grabowski 2006), strength of trophic cascades, and occurrence of intraguild predation (Finke \& Denno 2002, 2006, Grabowski et al. 2008).

Despite the importance of habitat heterogeneity in mediating the relationship between trophic interactions, biodiversity and ecosystem functioning, to our knowledge no study has manipulated predator richness (3 or more species) and habitat heterogeneity concomitantly. Here, we carried out a mesocosm experiment manipulating the identity and richness of estuarine predator species (blue crab Callinectes sapidus, sand shrimp Crangon septemspinosa, and grass shrimp Palaemonetes pugio) and habitat heterogeneity to test their influence on resource use effectiveness, competition among predators, and the trophic cascade to basal prey. We hypothesized that increasing predator species richness and habitat heterogeneity would each increase suppression of intermediate prey (mysid crustaceans) because of complementarity among predators that is better expressed in more complex habitats, and that these impacts should reduce grazing by mysids on basal prey (microalgae) through a cascading effect of predator richness on microalgae.

\section{MATERIALS AND METHODS}

\section{Experimental design}

We carried out a mesocosm experiment in outdoor tanks supplied with water from the York River estuary, Virginia, USA, where the organisms were collected. Flowing estuarine water was filtered through $150 \mu \mathrm{m}$ mesh bags to avoid invasion of large organisms, but allowing colonization by microalgae. Water was distributed to the mesocosms through a dumpbucket system. We manipulated predator species richness and habitat heterogeneity in the presence/ absence of prey through 14 distinct treatments (Table 1), implemented in 70 mesocosms of 181 , from 22 October to 5 November 2013 (14 d). We used a replacement design, i.e. we manipulated predator richness and identity maintaining the number of individual predators constant at 3 individuals per mesocosm. We chose a replacement instead of an additive design because the former more rigorously detects

Table 1. Experimental design. Initial number of mysids (intermediate consumers) and of each predator species, and habitat complexity level (homogeneous or heterogeneous) in each treatment

\begin{tabular}{|c|c|c|c|c|c|}
\hline Treatment & Mysid & Sand shrimp & $\begin{array}{l}\text { - Predator } \\
\text { Grass shrimp }\end{array}$ & Blue crab & Habitat \\
\hline 1 & 15 & 0 & 0 & 0 & Homogeneous \\
\hline 2 & 15 & 3 & 0 & 0 & Homogeneous \\
\hline 3 & 15 & 0 & 3 & 0 & Homogeneous \\
\hline 4 & 15 & 0 & 0 & 3 & Homogeneous \\
\hline 5 & 15 & 1 & 1 & 1 & Homogeneous \\
\hline 6 & 0 & 1 & 1 & 1 & Homogeneous \\
\hline 7 & 0 & 0 & 0 & 0 & Homogeneous \\
\hline 8 & 15 & 0 & 0 & 0 & Heterogeneous \\
\hline 9 & 15 & 3 & 0 & 0 & Heterogeneous \\
\hline 10 & 15 & 0 & 3 & 0 & Heterogeneous \\
\hline 11 & 15 & 0 & 0 & 3 & Heterogeneous \\
\hline 12 & 15 & 1 & 1 & 1 & Heterogeneous \\
\hline 13 & 0 & 1 & 1 & 1 & Heterogeneous \\
\hline 14 & 0 & 0 & 0 & 0 & Heterogeneous \\
\hline
\end{tabular}


interspecific and intraspecific predation, as well as complementarity effects among multiple predators (Byrnes \& Stachowicz 2009). The 14 treatments (5 replicates each) included: (1) mysids alone (predator control), to evaluate mysid survival without predators; (2-4) monocultures of each of the 3 predators with prey; predator polycultures (5) with and (6) without prey; (7) algae alone (consumer control treatment), containing neither predators nor prey, as a baseline to evaluate grazing impact on algae (Table 1: homogeneous habitat treatments); and (814) all of these same treatments within a physically structured habitat (Table 1: heterogeneous habitat treatments). Thus, the food chain in the mesocosms had 3 levels: benthic microalgae (basal prey), mysids (intermediate prey) and predators (top consumers). Mesocosms were open at the top, but covered with screens to prevent predator escape.

\section{Community assembly}

One week prior to the introduction of predators, 15 adult mysids (intermediate prey) were introduced into the mesocosms and allowed to acclimate. We chose mysids as prey because they are one of the main intermediate consumers in coastal waters (Miyashita \& Calliari 2016), including the Chesapeake Bay (Markle \& Grant 1970, Latour et al. 2008). Mysids are hyperbenthic organisms, having a major role in benthic-pelagic coupling, as they usually stay close to the bottom during the day and migrate to the water column during nighttime (Jumars 2007). We selected the numerically dominant mysid species in the field at the time of the experiment: Americamysis bahia. Adults of A. bahia reach a total length of approximately $6 \mathrm{~mm}$. Mysids are omnivorous: they eat detritus, algae, and small invertebrates (Mauchline 1980).

We introduced 3 predator individuals into each mesocosm (number potentially representative of natural predator abundances in estuarine systems), either 3 of a single species, or one of each of the 3 species in the combined treatment (polyculture). The predators chosen, and their individual mean $\pm \mathrm{SE}$ wet mass and length, were the sand shrimp Crangon septemspinosa $(0.27 \pm 0.08 \mathrm{~g} ; 31.1 \pm 0.9 \mathrm{~mm})$, the grass shrimp Palaemonetes pugio $(0.20 \pm 0.04 \mathrm{~g}$; $28.7 \pm$ $0.7 \mathrm{~mm}$ ), and juveniles of the blue crab Callinectes sapidus $(0.76 \pm 0.33 \mathrm{~g} ; 15.9 \pm 0.9 \mathrm{~mm})$. We selected predators of each species of similar size to avoid biomass differences among mesocosm replicates. These highly abundant predators in the Chesapeake Bay
(Douglass et al. 2010) are omnivorous (Morgan 1980, Taylor \& Peck 2004, Douglass et al. 2011, Seitz et al. 2011) and are expected to consume mysids (Price 1962, Morgan 1980, Fantle et al. 1999). The 3 predator species play an essential role in the carbon flux of marine coastal waters, as they serve as a major link between the base of the food webs (producers and primary consumers) and upper-level consumers, such as birds (Kent 1986) and fish species (Scharf \& Schlicht 2000, Clark et al. 2003, Kelly \& Hanson 2013).

The mesocosms representing the homogeneous habitat were left without any structure, whereas the heterogeneous habitat was created by introducing the macroalga Gracilaria sp. and dry shells from the eastern oyster Crassostrea virginica into the mesocosms $48 \mathrm{~h}$ prior to the introduction of mysids. We selected dry oyster shells of similar size in enough quantity to cover only the bottom of the mesocosms. Gracilaria sp. was defaunated before its introduction into the mesocosms by soaking in freshwater for 2-3 $\mathrm{h}$, followed by careful visual inspection after rinsing in freshwater. We added approximately $10 \mathrm{~g}$ of Gracilaria sp. wet mass in each mesocosm. Gracilaria sp. was weighed after removing excess water using a salad spinner (70 revolutions).

At the end of experiments, all invertebrates (mysids and predators) from the mesocosms were fixed in $70 \%$ ethanol for counting at the laboratory. To quantify microalgal biomass (chlorophyll a), microalgae were randomly sampled at a fixed depth from the wall of the mesocosms (2 samples of $\left.10 \mathrm{~cm}^{2}\right)$ and analyzed with a spectrophotometer (Jeffrey \& Humphrey 1975). Gracilaria sp. wet mass was measured as described above.

\section{Statistical analyses}

We calculated the reduction of mysid abundance as the response variable to test the predators' efficiency, whereas change in microalgal biomass was used to test for cascading effects. Mysid reduction was calculated as the difference between the mean abundance of mysids in the absence of predators and their mean abundance in each predator treatment. The initial and final abundance of mysids in the predator-free treatments in both homogeneous and heterogeneous habitats were compared with a $t$-test to verify mysid survival without predators during the experiment. The influence of habitat heterogeneity on mysid survival without predators (Table 1: Treatments 1 and 8) and on final biomass of microalgae without con- 
sumers (Table 1: Treatments 7 and 14) was also examined through a $t$-test by comparing the homogeneous treatment with its analogous heterogeneous treatment. One-way ANOVA was applied to homogeneous and heterogeneous treatments separately to verify differences in mysid suppression and microalgal biomass. Gracilaria sp. mass was also analyzed with 1-way ANOVA among those treatments in which it was stocked. Finally, differences in mysid abundance, microalgal biomass, and predator survival (number of predators that survived until the end of the experiment; all treatments containing predators were included in the analysis) between treatments were analyzed with 2-way ANOVA (factors: predator species composition and habitat heterogeneity). Significant treatment effects were clarified through post hoc Tukey's HSD tests. Homogeneity of variances and normality of the data were tested, and when necessary a $\log (x+1)$ transformation was used to normalize the data (only the predator survival data had to be transformed) to meet the statistical assumptions of ANOVA.

We used a planned linear contrast to compare the mean prey suppression of the monocultures with the polyculture to test for non-transgressive overyielding effects. The occurrence of transgressive overyielding was also verified by comparing the best-performing monoculture with the polyculture.

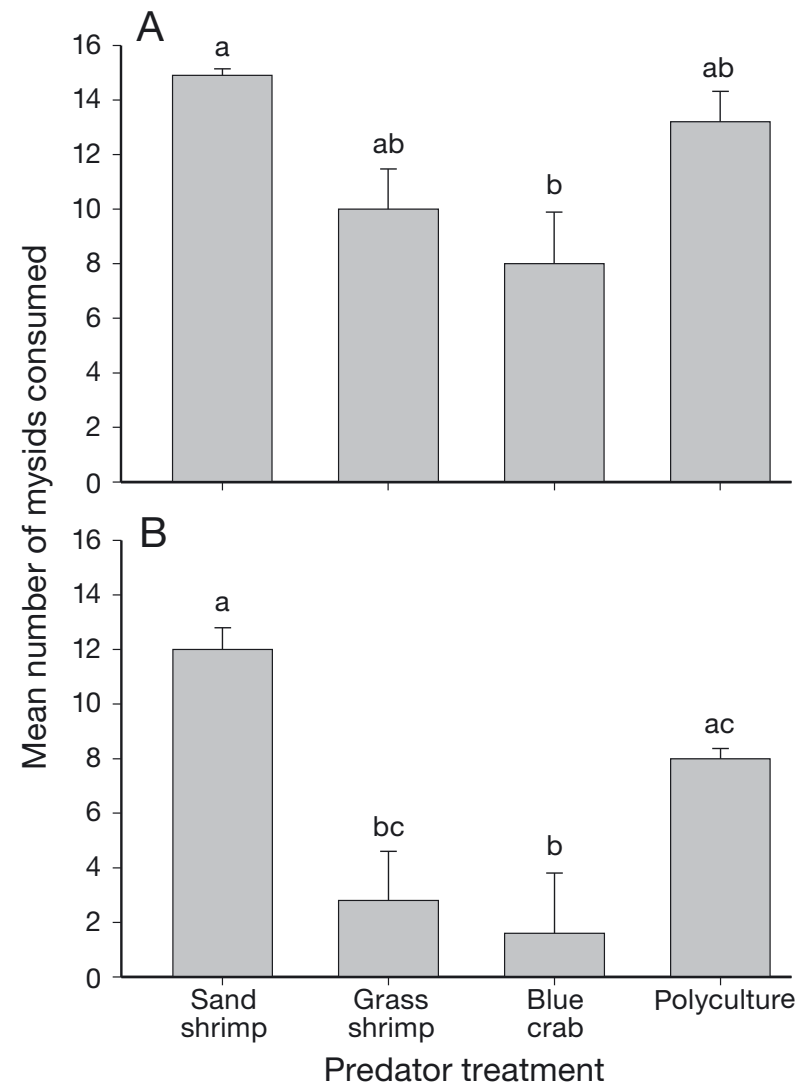

Fig. 1. Mean number of mysids consumed in each predator treatment in the (A) heterogeneous and (B) homogeneous habitats. Error bars represent the standard error. Bars with different letters are significantly different according to Tukey's HSD $(\alpha=0.05)$

\section{RESULTS}

Suppression of mysid prey differed strongly among predator treatments, but all predators were more effective in the heterogeneous habitat (Fig. 1). Habitat heterogeneity alone did not influence mysid abundance ( $t$-test, $\mathrm{p}=$ $0.540)$ or microalgal biomass $(\mathrm{p}=$ 0.321), as the control treatments of both variables did not differ significantly between homogeneous and heterogeneous habitats. Moreover, mysid mortality and/or recruitment was negligible without predators, as indicated by no significant differences between their initial and final abundances in the control treatments during the experiment ( $t$-test, $\mathrm{p}>0.06)$. Predator treatment and habitat heterogeneity affected mysid suppression (2-way ANOVA, p < 0.001), but there was no interaction among treatments ( $\mathrm{p}=0.44$; Table 2$)$. The grass
Table 2. Results of 2-way ANOVAs related to suppression of mysid abundance, microalgae biomass and (log) predator survival. Significant $p$-values $(\mathrm{p}<0.05)$ are in bold

\begin{tabular}{|lccccc|}
\hline Response variable and factor & df & SS & MS & $F$ & $\mathrm{p}$ \\
\hline Prey suppression & & & & & \\
Predator & 3 & 461.6 & 153.9 & 15.464 & $<\mathbf{0 . 0 0 1}$ \\
Habitat & 1 & 176.4 & 176.4 & 17.729 & $<\mathbf{0 . 0 0 1}$ \\
Predator $\times$ Habitat & 3 & 27.6 & 9.2 & 0.925 & 0.44 \\
Error & 32 & 318.4 & 9.9 & & \\
Total & 39 & 984 & & & \\
& & & & & \\
Microalgae biomass & & & & & \\
Predator & 3 & 0.073 & 0.0243 & 1165 & 0.338 \\
Habitat & 1 & 0.0546 & 0.0546 & 2613 & 0.116 \\
Predator $\times$ Habitat & 3 & 0.0281 & 0.00938 & 0.449 & 0.72 \\
Error & 32 & 0.668 & 0.0209 & & \\
Total & 39 & 0.824 & 0.0211 & & \\
& & & & & \\
Predator survival & & & & & \\
Predator & 4 & 0.0974 & 0.0244 & 3.351 & $\mathbf{0 . 0 1 9}$ \\
Habitat & 1 & 0.0907 & 0.0907 & 12.482 & $\mathbf{0 . 0 0 1}$ \\
Predator $\times$ Habitat & 4 & 0.163 & 0.0406 & 5.59 & $\mathbf{0 . 0 0 1}$ \\
Error & 40 & 0.291 & 0.00727 & & \\
Total & 49 & 0.641 & 0.0131 & & \\
\hline
\end{tabular}


shrimp (ANOVA, $\mathrm{p}<0.0001)$ and the blue crab $(\mathrm{p}=$ 0.004 ) preyed significantly on mysids only in the heterogeneous habitat (Fig. 1), whereas the sand shrimp and the predator polyculture suppressed mysids significantly in both habitats $(\mathrm{p}<0.005)$.

We did not observe transgressive overyielding, i.e. the total in the predator polycultures did not exceed that of the sand shrimp, which was the best-performing single predator species in both homogeneous and heterogeneous habitat treatments. Although the predator polyculture consumed more mysids (mean \pm $\mathrm{SE}$; homogeneous habitat: $8.0 \pm 0.8$ mysids; heterogeneous habitat: $12.6 \pm 1.1$ mysids) compared with the mean of the 3 predator monocultures (homogeneous habitat: $5.5 \pm 1.5$ mysids; heterogeneous habitat: $10.3 \pm 1.1$ mysids), they did not differ significantly (planned linear contrast, homogeneous habitat: $\mathrm{p}=$ 0.161; heterogeneous habitat: $\mathrm{p}=0.158$ ), indicating absence of non-transgressive overyielding effects.

Microalgal biomass had lower values in the blue crab and grass shrimp monocultures in the homogeneous habitat, which may suggest some microalgae grazing by these predators (Fig. 2). However, microalgal biomass did not vary significantly between treatments in homogeneous and heterogeneous habitats (ANOVA, p > 0.42; Fig. 2) and was not affected by predator species composition (2-way ANOVA, $p=$ $0.338)$, habitat heterogeneity $(\mathrm{p}=0.116)$, or their interaction ( $p=0.72$; Table 2). Thus, no trophic cascades were observed, as predator reduction of mysid abundance did not influence microalgal biomass.

Change in Gracilaria sp. wet mass was lower in the monocultures and the predator-free control treatment, and higher in the predator polyculture without prey and the microalgae-alone treatment (Fig. 3). This result may indicate some Gracilaria sp. consumption by mysids and predators, although the treatments did not differ significantly (ANOVA, $\mathrm{p}=0.165$ ).

Predator survival was affected by predator treatment ( 2 -way ANOVA, $p=0.019)$, habitat heterogeneity ( $p=0.001)$, and their interaction ( $p=0.001$; Table 2$)$. This was evident mainly for the blue crab (Fig. 4), which had significantly higher survival rates in the heterogeneous habitat (Tukey's HSD, $\mathrm{p}<0.001$ ).

\section{DISCUSSION}

Our experiment showed that predator species differed strongly in ability to suppress prey, multi-species predator assemblages were more effective than the average single predator, and predator effectiveness and survival were enhanced by habitat hetero-

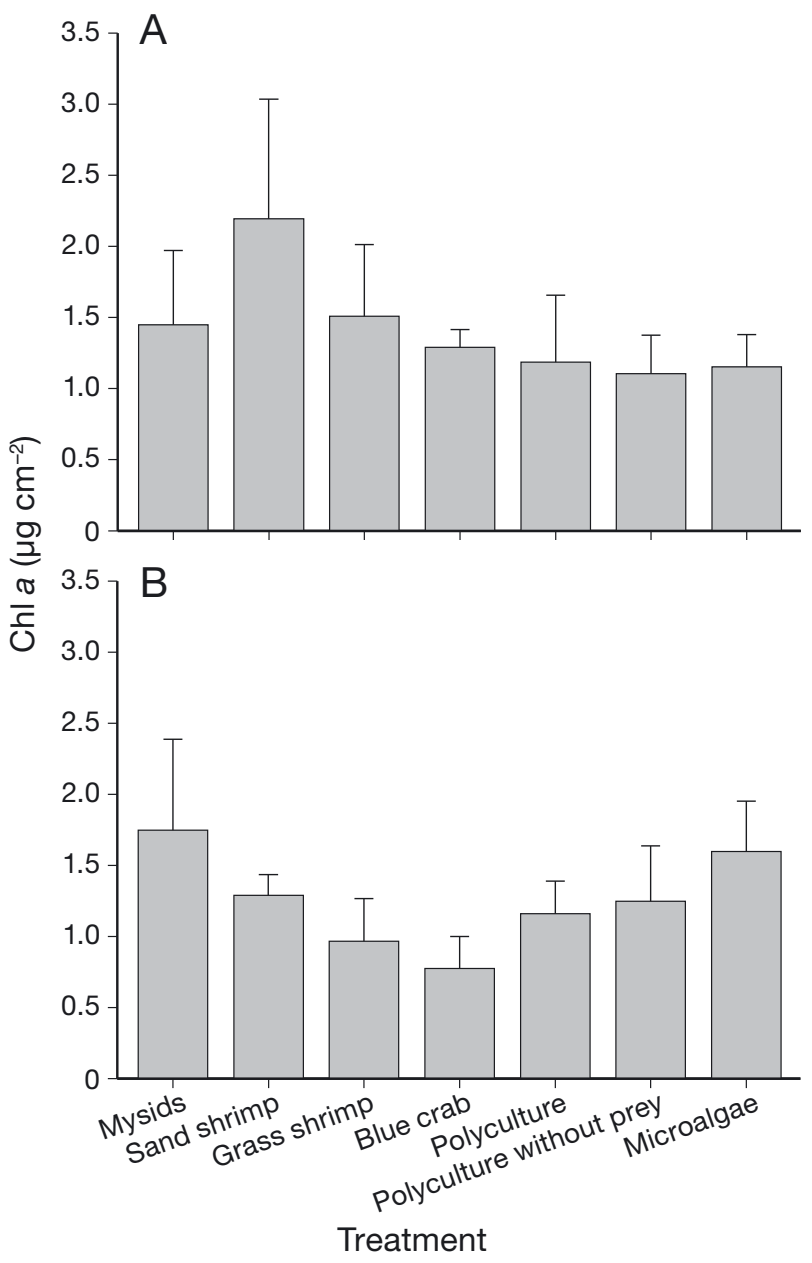

Fig. 2. Mean microalgal biomass in each treatment in the (A) heterogeneous and (B) homogeneous habitats. Error bars represent the standard error

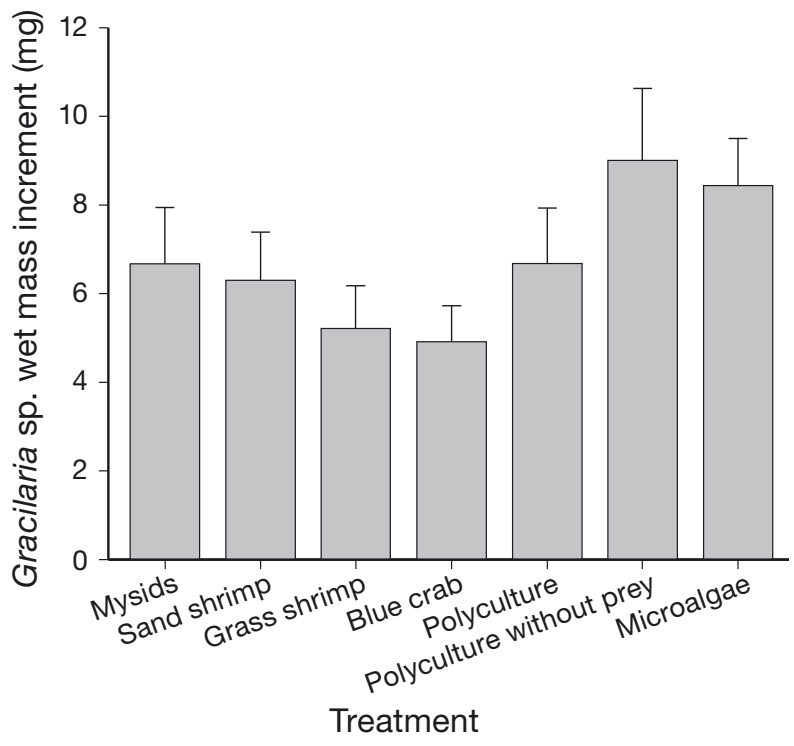

Fig. 3. Mean Gracilaria sp. wet mass increment during the experiment. Error bars represent the standard error 


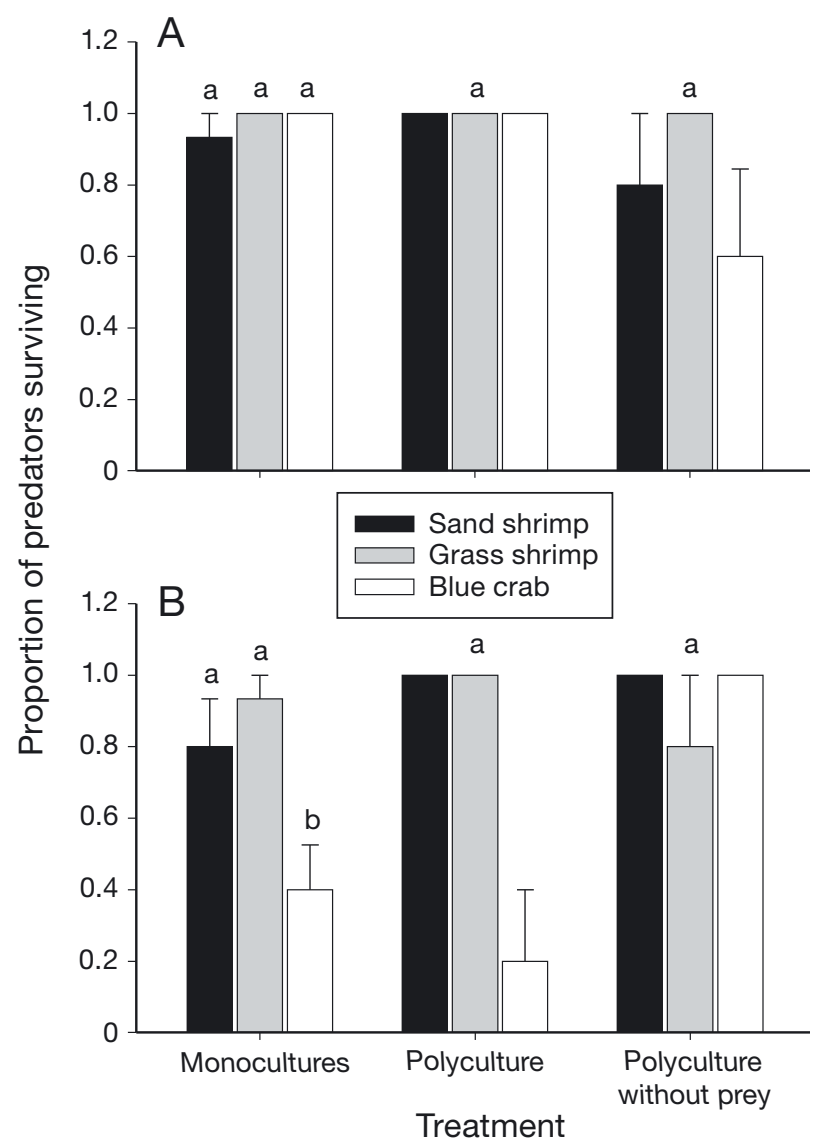

Fig. 4. Mean proportion of predators surviving at the end of the experiment in each predator treatment in the (A) heterogeneous and (B) homogeneous habitats. Error bars represent the standard error. Bars with different letters are significantly different according to Tukey's HSD $(\alpha=0.05)$

geneity. All predator treatments were more efficient at suppressing prey in the more heterogeneous habitat; however, the importance of habitat heterogeneity was singular for each species, probably related to the specific behavior and feeding mode of each predator. The sand shrimp was the most effective predator species in both homogeneous and heterogeneous habitats, and apparently was the species least dependent on habitat heterogeneity to suppress prey. The 3 predator species used in the experiment are bottom dwellers, but the sand shrimp, in contrast to the grass shrimp and the blue crab, is a nocturnal opportunistic predator (Taylor \& Peck 2004) that migrates to the water column during nighttime (Brown et al. 2014). This migratory behavior may have increased predator-prey encounter rates, which may explain the higher mysid suppression by the sand shrimp independently of habitat heterogeneity. Conversely, the grass shrimp and the blue crab only preyed effectively on mysids in the more heterogeneous habitat.
These 2 predators generally occur in association with foundation species such as submerged aquatic vegetation and oyster reefs (Douglass et al. 2010, Shervette et al. 2011), where they usually have higher predation success (Ryer 1987, Gregg \& Fleeger 1998) and survival (Hovel \& Lipcius 2002, Mattila et al. 2008) than in more homogeneous environments, as observed in our experiment. The grass shrimp especially took advantage of the physical structure provided by Gracilaria sp., to which it was frequently seen clinging, as already shown for this shrimp species (Khan et al. 1997). The vertical structure provided by the macroalgae seemed to: (1) segregate the grass shrimp from the other 2 predator species; (2) allow this generalist shrimp predator to access prey higher in the water column; and (3) provide a refuge from which to ambush the mysids. For the blue crab, habitat heterogeneity visibly influenced survival rates, likely because of its high intraspecific aggressiveness (Mansour \& Lipcius 1991, Clark et al. 1999) and cannibalistic behavior (Hines et al. 1990, Moksnes et al. 1997). Therefore, the higher prey suppression of the blue crab in the more heterogeneous habitat was probably a consequence of less agonistic behavior and/or reduced intraspecific predation. Thus, the distinct interaction of each predator species with habitat heterogeneity allowed interspecific niche partitioning among the 3 predators to be better expressed, resulting in higher prey suppression because of complementarity effects (Cardinale et al. 2004, Griffin et al. 2009).

The pattern of highest predation by the sand shrimp, followed by the predator polyculture, indicates that both predator identity and diversity influenced the efficiency of the assemblage to remove prey (Bruno \& O'Connor 2005, Douglass et al. 2008). Our data are consistent with results of a meta-analysis that showed that predator richness generally enhances prey suppression relative to the mean performance of predator monocultures, but not in comparison to the most effective predator (Griffin et al. 2013). This trend implies that maximum prey suppression, i.e. energy fluxes from prey to predator assemblages, would diminish with loss of predator diversity only if the most effective predator disappears (and assuming that predator density remains constant). However, in natural ecosystems, different species usually maximize distinct ecosystem processes (Duffy 2009, Lefcheck et al. 2015); hence, reduced predator diversity is likely to alter any of several processes mediated through top-down forcing and cascade through consumers to producers (Finke \& Denno 2004, Duffy et al. 2007, Bruno \& Cardinale 
2008), consequently affecting ecosystem functions such as production and decomposition.

Despite the ubiquity of trophic cascades in the marine benthos (Shurin et al. 2002), we did not observe any sign of the influence of predator identity and diversity on the occurrence of a trophic cascade. We expected a trophic cascade whereby predator richness indirectly increases algal biomass via predation on grazing mysids. Yet, mysids did not graze on benthic microalgae to a significant extent, probably because they are omnivorous generalist consumers (Mauchline 1980, Jumars 2007). Thus, in addition to benthic microalgae, they might have fed on other food sources, such as detritus, phytoplankton, and tiny invertebrates (e.g. harpacticoid copepods), present in the mesocosms. Conversely, mysids seemed to consume Gracilaria sp.; however, no trophic cascade was observed in this case either, because predators also seemed to feed on this macroalgae. In this case, the omnivorous character of predators dampened a trophic cascade (Bruno \& O'Connor 2005, Johnson et al. 2014).

In summary, we observed that complementarity effects between predator species were fostered in a more heterogeneous habitat, apparently because of niche partitioning, which leads to higher prey suppression and survival of predators. These findings indicate that the loss of both biodiversity and habitat heterogeneity can alter processes that affect energy flux in marine food webs, although the exact consequences are hard to predict because of their complex interaction. Therefore, conservation of both biodiversity and habitat heterogeneity are considerations for the appropriate management of natural ecosystems.

Acknowledgements. We thank S. Chak, J. Lefcheck, K. Gadeken, D. Hall, and S. Ziegler for their help with the mesocosm experiment, and D. Calliari for comments and text editing on an earlier version of this manuscript. L.K.M. was supported by the National Council for Scientific and Technological Development (CNPq, grants 142203/2010-6, 142050/2012-1 and 245466/2012-6).

\section{LITERATURE CITED}

Altieri AH, van de Koppel J (2014) Foundation species in marine ecosystems. In: Bertness MD, Bruno JF, Silliman BR, Stachowicz JJ (eds) Marine community ecology and conservation. Sinauer Associates, Sunderland, MA, p 37-56

Brown H, Bollens SM, Brown GS (2014) Vertical distribution and diel migration of Crangon septemspinosa Say, 1818 (Decapoda, Caridea) on Georges Bank, northwest Atlantic. Crustaceana 87:1486-1499

Bruno JF, Cardinale BJ (2008) Cascading effects of predator richness. Front Ecol Environ 6:539-546
Bruno JF, O'Connor MI (2005) Cascading effects of predator diversity and omnivory in a marine food web. Ecol Lett 8: 1048-1056

Byrnes JE, Stachowicz JJ (2009) The consequences of consumer diversity loss: different answers from different experimental designs. Ecology 90:2879-2888

> Cardinale BJ, Ives AR, Inchausti P (2004) Effects of species diversity on the primary productivity of ecosystems: extending our spatial and temporal scales of inference. Oikos 104:437-450

Cardinale BJ, Srivastava DS, Duffy JE, Wright JP, Downing AL, Sankaran M, Jouseau C (2006) Effects of biodiversity on the functioning of trophic groups and ecosystems. Nature 443:989-992

Cardinale BJ, Matulich KL, Hooper DU, Byrnes JE and others (2011) The functional role of producer diversity in ecosystems. Am J Bot 98:572-592

Cardinale BJ, Duffy JE, Gonzalez A, Hooper DU and others (2012) Biodiversity loss and its impact on humanity. Nature 486:59-67

Clark ME, Wolcott TG, Wolcott DL, Hines AH (1999) Foraging and agonistic activity co-occur in free-ranging blue crabs (Callinectes sapidus): observation of animals by ultrasonic telemetry. J Exp Mar Biol Ecol 233:143-160

Clark KL, Ruiz GM, Hines AH (2003) Diel variation in predator abundance, predation risk and prey distribution in shallow-water estuarine habitats. J Exp Mar Biol Ecol 287:37-55

Douglass JG, Duffy JE, Bruno JF (2008) Herbivore and predator diversity interactively affect ecosystem properties in an experimental marine community. Ecol Lett 11:598-608

> Douglass JG, France KE, Richardson JP, Duffy JE (2010) Seasonal and interannual change in a Chesapeake Bay eelgrass community: insights into biotic and abiotic control of community structure. Limnol Oceanogr 55:1499-1520

- Douglass JG, Duffy JE, Canuel EA (2011) Food web structure in a Chesapeake Bay eelgrass bed as determined through gut contents and ${ }^{13} \mathrm{C}$ and ${ }^{15} \mathrm{~N}$ isotope analysis. Estuaries Coasts 34:701-711

Duffy JE (2009) Why biodiversity is important to the functioning of real-world ecosystems. Front Ecol Environ 7: 437-444

> Duffy JE, Richardson JP, France K (2005) Ecosystem consequences of diversity depend on food chain length in estuarine vegetation. Ecol Lett 8:301-309

> Duffy JE, Cardinale BJ, France KE, McIntyre PB, Thebault E, Loreau M (2007) The functional role of biodiversity in ecosystems: incorporating trophic complexity. Ecol Lett 10:522-538

Duffy JE, Lefcheck JS, Stuart-Smith RD, Navarrete SA, Edgar GJ (2016) Biodiversity enhances reef fish biomass and resistance to climate change. Proc Natl Acad Sci USA 113:6230-6235

Fantle MS, Dittel AI, Schwalm SM, Epifanio CE, Fogel ML (1999) A food web analysis of the juvenile blue crab, Callinectes sapidus, using stable isotopes in whole animals and individual amino acids. Oecologia 120:416-426

> Finke DL, Denno RF (2002) Intraguild predation diminished in complex-structured vegetation: implications for prey suppression. Ecology 83:643-652

> Finke DL, Denno RF (2004) Predator diversity dampens trophic cascades. Nature 429:407-410

> Finke DL, Denno RF (2006) Spatial refuge from intraguild predation: implications for prey suppression and trophic cascades. Oecologia 149:265-275 
Gamfeldt L, Lefcheck JS, Byrnes JEK, Cardinale BJ, Duffy JE, Griffin JN (2015) Marine biodiversity and ecosystem functioning: What's known and what's next? Oikos 124: 252-265

Godbold JA, Bulling MT, Solan M (2011) Habitat structure mediates biodiversity effects on ecosystem properties. Proc R Soc B 278:2510-2518

- Grabowski JH, Powers SP (2004) Habitat complexity mitigates trophic transfer on oyster reefs. Mar Ecol Prog Ser 277:291-295

Grabowski JH, Hughes AR, Kimbro DL (2008) Habitat complexity influences cascading effects of multiple predators. Ecology 89:3413-3422

Gregg CS, Fleeger JW (1998) Grass shrimp Palaemonetes pugio predation on sediment- and stem-dwelling meiofauna: field and laboratory experiments. Mar Ecol Prog Ser 175:77-86

> Griffin JN, Jenkins SR, Gamfeldt L, Jones D, Hawkins SJ, Thompson RC (2009) Spatial heterogeneity increases the importance of species richness for an ecosystem process. Oikos 118:1335-1342

> Griffin JN, Byrnes JEK, Cardinale BJ (2013) Effects of predator richness on prey suppression: a meta-analysis. Ecology 94:2180-2187

Gutiérrez JL, Jones CG, Strayer DL, Iribarne OO (2003) Mollusks as ecosystem engineers: the role of shell production in aquatic habitats. Oikos 101:79-90

> Hines AH, Haddon AM, Wiechert LA (1990) Guild structure and foraging impact of blue crabs and epibenthic fish in a subestuary of Chesapeake Bay. Mar Ecol Prog Ser 67: 105-126

> Hovel KA, Lipcius RN (2002) Effect of seagrass habitat fragmentation on juvenile blue crab survival and abundance. J Exp Mar Biol Ecol 271:75-98

> Hughes AR, Grabowski JH (2006) Habitat context influences predator interference interactions and the strength of resource partitioning. Oecologia 149:256-264

Isbell F, Craven D, Connolly J, Loreau M and others (2015) Biodiversity increases the resistance of ecosystem productivity to climate extremes. Nature 526:574-577

Jeffrey SW, Humphrey GF (1975) New spectrophotometric equations for determining chlorophylls $a, b, c 1$, and $c 2$ in higher plants, algae and natural phytoplankton. Biochem Physiol Pflanz 167:191-194

> Johnson KD, Grabowski JH, Smee DL (2014) Omnivory dampens trophic cascades in estuarine communities. Mar Ecol Prog Ser 507:197-206

> Jumars PA (2007) Habitat coupling by mid-latitude, subtidal, marine mysids: import-subsidised omnivores. Oceanogr Mar Biol Annu Rev 45:89-138

Kelly JT, Hanson JM (2013) Maturity, size at age and predator-prey relationships of winter skate Leucoraja ocellata in the southern Gulf of St Lawrence: potentially an undescribed endemic facing extirpation. J Fish Biol 82: 959-978

Kent DM (1986) Behavior, habitat use, and food of three egrets in a marine habitat. Colon Waterbirds 9:25-30

Khan RN, Merchant HC, Knowlton RE (1997) Effects of macrophytic cover on the distribution of grass shrimps,

Editorial responsibility: Martin Solan,

Southampton, UK
Palaemonetes pugio and P. vulgaris. Invertebr Biol 116: 243-247

Latour RJ, Gartland J, Bonzek CF, Johnson RA (2008) The trophic dynamics of summer flounder (Paralichthys dentatus) in Chesapeake Bay. Fish Bull 106:47-57

Lefcheck JS, Byrnes JEK, Isbell F, Gamfeldt L and others (2015) Biodiversity enhances ecosystem multifunctionality across trophic levels and habitats. Nat Commun 6:6936

Mansour RA, Lipcius RN (1991) Density-dependent foraging and mutual interference in blue crabs preying upon infaunal clams. Mar Ecol Prog Ser 72:239-246

- Markle DF, Grant GC (1970) The summer food habits of young-of-the year striped bass in three Virginia rivers. Chesap Sci 11:50-54

> Mattila J, Heck KL Jr, Millstein E, Miller E, Gustafsson C, Williams S, Byron D (2008) Increased habitat structure does not always provide increased refuge from predation. Mar Ecol Prog Ser 361:15-20

Mauchline J (1980) The biology of mysids and euphausiids. Adv Mar Biol 18:1-681

Miyashita LK, Calliari D (2016) Distribution and salinity tolerance of marine mysids from a subtropical estuary, Brazil. Mar Biol Res 12:133-145

> Moksnes PO, Lipcius RN, Pihl L, van Montfrans J (1997) Cannibal-prey dynamics in young juveniles and postlarvae of the blue crab. J Exp Mar Biol Ecol 215:157-187

> Morgan MD (1980) Grazing and predation of the grass shrimp Palaemonetes pugio. Limnol Oceanogr 25:896-902

Polis GA, Holt RD (1992) Intraguild predation — the dynamics of complex trophic interactions. Trends Ecol Evol 7:151-154

Price KS Jr (1962) Biology of the sand shrimp, Crangon septemspinosa, in the shore zone of the Delaware Bay region. Chesap Sci 3:244-255

Ryer CH (1987) Temporal patterns of feeding by blue crabs (Callinectes sapidus) in a tidal-marsh creek and adjacent seagrass meadow in the lower Chesapeake Bay. Estuaries 10:136-140

Scharf FS, Schlicht KK (2000) Feeding habits of red drum (Sciaenops ocellatus) in Galveston Bay, Texas: seasonal diet variation and predator-prey size relationships. Estuaries 23:128-139

Seitz RD, Knick KE, Westphal M (2011) Diet selectivity of juvenile blue crabs (Callinectes sapidus) in Chesapeake Bay. Integr Comp Biol 51:598-607

Shervette VR, Gelwick F, Hadley N (2011) Decapod utilization of adjacent oyster, vegetated marsh, and non-vegetated bottom habitats in a Gulf of Mexico estuary. J Crustac Biol 31:660-667

Shurin JB, Borer ET, Seabloom EW, Anderson K and others (2002) A cross-ecosystem comparison of the strength of trophic cascades. Ecol Lett 5:785-791

Stachowicz JJ (2001) Mutualism, facilitation, and the structure of ecological communities. Bioscience 51:235-246

Stachowicz JJ, Bruno JF, Duffy JE (2007) Consequences of biodiversity for marine communities and ecosystems. Annu Rev Ecol Evol Syst 38:739-766

Taylor DL, Peck MA (2004) Daily energy requirements and trophic positioning of the sand shrimp Crangon septemspinosa. Mar Biol 145:167-177

Submitted: March 17, 2016; Accepted: September 9, 2016 Proofs received from author(s): October 15, 2016 